\title{
7 Contestations of citizenship
}

\author{
Migrant labour, a benevolent \\ state, and the COVID-19-induced \\ lockdown in Kerala
}

\author{
Praveena Kodoth
}

\section{Introduction}

The mass exodus of migrant labour in the wake of the national lockdown in March 2020 exposed more than the central government's lack of planning and sensitivity to the conditions of this labour force; it provided a sudden but spontaneous visibility to the full force of the distress and insecurity of migrant workers. To make sense of this harsh reality, it is necessary to go beyond the relationship between this precarious workforce and the nation-state at a time of crisis and to reckon with the more routine failures of citizenship that metamorphosed into a crisis in the first place. The central government was caught off guard by the swiftness with which migrant workers headed back home, indicating a serious lack of awareness and understanding of this workforce. ${ }^{1}$ Kerala, however, stood out for the speed with which the government announced a relief package, mobilised volunteers, and instituted measures to mitigate distress with an emphasis on workers who depend on daily earnings and migrant labour. With coordination at various levels of government and communication through the media, the government showed readiness to address gaps in the design and implementation of relief measures. In several migrant hubs, when workers mobilised in public demanding to go back home, government authorities intervened quickly to diffuse protests.

The state government's response to the humanitarian crisis was marked by a rare degree of concern. However, the government employed a rhetoric of care that, along with some hostile public perceptions of migrant workers, brought into view the undermining of the citizenship of migrant workers. The government's insistence on addressing migrant workers as 'guest workers', while suggesting that Kerala as the host state was obliged to provide care steered away, inevitably, from a language of citizenship obligations and rights. Pratap Bhanu Mehta (2020) points out: 'There is something deeply morally odd in using the language of compassion in relation to 
the state. What we need from the state is not compassion; it is a minimum sense of justice. In fact, the appeals to compassion destructively depoliticise social policy by appealing to sentiment'. Thus, the depiction of protests by migrant workers in everyday conversations as 'ingratitude' fitted well within the state's approach.

Migrant labourers are considered indispensable to Kerala's economy. If their exodus forced them into full public view across the country, they were already visible in Kerala, i.e., there was recognition of their presence, albeit in specific forms. A form of state-conferred visibility in the form of pioneering welfare schemes offered migrant workers the possibility of at least minimal social protection. ${ }^{2}$ But migrant workers laid claim to a more contentious form of visibility. For instance, they have sought to mark their identity and achieve solidarity by coming together in public places like a Sunday market in Perambavoor, a large migrant hub near Ernakulum, and by engaging sporadically in protests (Prasad, M., 2016). Migrant hubs have theatres screening Hindi, Odiya, and Bengali films and churches that hold mass for migrant workers in their languages (Sudhir, 2016), which also merit study as distinctive spaces for marking identity. The state-society complex in Kerala, which includes the police and other government agencies, mainstream trade unions and the Malayali public have been implicated in curtailing freedoms of expression, assembly, and association of migrant workers. For instance, Prasad Aleyamma (2017) points out with reference to Perambavoor that migrant workers are produced as a threat to public order, which serves to legitimise police harassment and to justify demands for surveillance.

I examine contestations of citizenship of migrant workers in Kerala during and before the lockdown as have been apparent in the stoking of suspicion and fear against them in the context of protests or when a crime is committed in a migrant hub. As public perceptions, police actions, and underlying social relations produce migrant workers as 'outsiders' and expose the fault lines of a benevolent state, I argue that state-conferred visibility in the form of welfare does not guarantee enfranchised citizenship. The undermining of migrant citizenship becomes even more apparent in contrast to Non Resident Keralites (NRKs) who are an important political constituency and are appealed to by the state in a language that grants them a position of privilege and power.

\section{Migrant labour and the lockdown response in Kerala}

A widely cited estimate derived from a study by the Gulati Institute of Finance and Taxation in 2013 puts the current number of inter-state migrant workers at more than 3.5 million. ${ }^{3}$ The major source states, West Bengal, Bihar, Assam, and Uttar Pradesh, accounted for about 70 per cent 
of migrants, with each of them contributing between 20 and 15 per cent. However, only 5.09 lakh migrant workers are registered under the Awas scheme (see note 2), a health insurance scheme administered by the labour department and a survey by the labour department during the lockdown enumerated a little over 4.34 lakh migrant workers in camps in the state. This may be only a fraction of migrant workers in the state. Problems of estimation of migrant workers, encountered nation-wide, are intertwined with the failure of governments to design and implement social protection (Samaddar, 2020b).

It is obvious that Kerala had better outreach and documentation of camps compared to other states. The first report submitted to the Supreme Court on 31 March 2020 in response to a PIL showed that Kerala accounted for 65 per cent of migrant shelter camps (18,912 migrant camps) and housed nearly 50 per cent of migrants (over 3 lakhs) documented across the country (Writ petition (Civil) No 468/2020). Considering Kerala's small population share and that it accounts for only a very small share of all migrant labour in the country, these are disproportionately large figures.

The state labour commissioner, who has received praise for his proactive responses, observed that 'the idea of camp was conceptual, rather than in physical terms' (G Plus news, 2020). The reference here is to the distribution of migrant labour in shelter camps arranged by the state government, employer-provided camps, and the difficult-to-enumerate rented accommodations across the state. However, it elides over the possibility that a large section of migrant labour were not enumerated. Nevertheless, official categorisation according to the nature of employment and residence streamlined planning. Decentralised executions of plans meant that there were variations according to districts, but it was apparent that workers in shelters were relatively well taken care of compared to workers whose contractors/ employers were expected to provide for their food and other basic needs (Arnimesh, 2020). Migrant protests were fuelled at least partly by the dearth of essential provisions among those who resided in rented accommodation (The Hindu, 29 March).

Reports indicate that officials acted on specific complaints when employers/contractors failed to make provision for food and water for workers. But in some instances, repeated appeals were made and higherlevel officials responded with alacrity where local officials had failed. The SWAN report noted that cases reported from Kerala were resolved with help from the local administration, but in one instance no action was taken even after follow-up. 'The workers also said that they were reluctant to call the control room as they were afraid of being harassed. The SWAN volunteers interceded with the District Collectorate and the matter was sorted out'. ${ }^{4}$ 


\section{6}

Praveena Kodoth

The labour commissioner's direct intervention enabled migrant workers from Kalahandi in Odisha who were detained by their employer to return home and ensured that the workers were paid their wages which their employer had held back (Jena, 2020), a tactic that is used by employers in the state to prevent workers from leaving. When it was reported that plantation owners and managers in Idukki were not able to provide food for migrant labour, the state government, based on investigation of a report from the Idukki district labour officer, gave instructions that migrant workers employed on plantations in Idukki district and not in possession of ration cards should be provided free rations that would be financed from the CMDRF/SDRF (G O no. 113/2020, Public Distribution Division).

Interventions by the state government underlined carefully devised strategies to prevent unrest. Measures were taken to reach out to migrant workers in their own languages through call centres and pamphlets, to ensure that they were able to communicate with their families back home, provision was made for monitoring of health, counselling services were set up, and even recreation facilities were provided in shelters. Recognising that the distress of migrant workers went beyond essential provisions, the state government was among the first to appeal to the Centre to run trains for them to return homes if they so desired. By June, nearly 58 per cent or 252,444 migrant workers enumerated in camps had left the state in 180 special trains from across the state (Sai Kiran, 2020). The measures taken by the state government during the lockdown were consistent with a pre-existing welfare approach but they must be seen alongside expressions of hostility and xenophobia against migrant workers (discussed in the following section).

\section{Inter-state migrant workers and citizenship in Kerala}

Explaining Kerala's performance in keeping the infection and death rates low in the first few months of the pandemic, Patrick Heller (2020) underscored the 'robust nature of Kerala's social compact' and likened the pandemic to a 'physical exam of the social body' that put public trust to its biggest ever test. However, if public trust has defined the state's ability in Kerala to 'elicit compliance' (a reference to the willingness of citizens to comply with the measures taken by the state), we also need to be attentive of the fractures in the social body in Kerala. With the rapidly increasing numbers of migrant workers in Kerala and as a section of them reside with their families, educate their children, and develop stronger stakes in local society, the social body in Kerala is clearly becoming more diverse. This reality pushes against the problems with an approach that evades the question of political rights. 
A case in point is the use of the term 'guest workers', which was meant to convey a caring approach. However, as migration scholar, Binoy Peter was quick to point out, by using the term, the 'government seems to be reminding them to leave after their work is finished, which is discriminatory. They have the right to be here' (cited in Paliath, 2020). The term is reminiscent of the guest worker programme in postwar Germany, which politely spelt out temporality in residence and the Kafala (guest) system in the Middle East that gives impunity to the police and nationals to discipline the immigrant workforce (Kodoth, 2020).

This is not merely an issue of nomenclature. In response to allegations of illegal migration and criminal activity, successive governments in Kerala have sought to increase bureaucratic controls over migrant workers. At one point, migrant workers were required to obtain police clearance cards that vouched for their credentials - their place of birth and lack of criminal antecedents (Prasad, 2017). Such mechanisms of control also recall immigration regimes for as Caroline Vandenabeele points out: 'Legal identity, or the right to be recognized by the government of the country of which one is a citizen, is a primary right that exists regardless of whether one has a document to prove this citizenship ... [O]fficial, government-issued and -recognized documents ... do not confer legal identity; they merely confirm it' (cited in Bhabha, 2011: 5).

Ironically, in Kerala, where workers' protests are staple fare, protests by migrant workers during the lockdown were used to stoke suspicion and fear. A sample of messages circulated on social media read: 'Migrant labourers from West Bengal, Assam, Bihar and UP could take control over Perambavoor town in less than 10 minutes. They will not allow us to flee. Our situation would become worse than that of Pandits, who fled Kashmir valley' (Ameerudhin, 2020).

The idea that migrant workers pose a threat to the territorial sovereignty of the Malayali people raises fundamental contestation of migrant citizenship. This notion of sovereignty is not threatened, however, by existing state-conferred visibility. A recent expression of state-conferred visibility in the form of the celebration of the achievements of the daughter of a migrant worker from Bihar is instructive. On 23 August 2020, Payal Kumari made headlines when she secured the first rank in the final examination of the history and archaeology course at the MG University in Kottayam. ${ }^{5}$ She was feted by the chief minister: 'What makes her success special is the fact that her parents are guest workers' (cited in Phillip, 2020). Interviewed widely, she was quoted as saying that her success belonged to Kerala and that she could not have made this kind of progress had her family remained in her home state (Kuriakose, 2020). As the media recounted the many acts of kindness from her teachers and school and college authorities that 
enabled her and her family to overcome seemingly unsurmountable odds, it was difficult to miss how the girl's achievements were presented as seamless with those of a socially progressive and caring state and a generous society.

Contrast this with the responsibility for crime committed by migrant workers which is systematically displaced on to the social body of migrants. A slew of allegations, mostly unsubstantiated, are levelled against migrant workers, suggesting that they are a threat to public order and public health as they engage in criminal activities, alcohol, and substance abuse, lack basic hygiene, and offer a safe haven for law breakers, terrorists, and illegal migrants. A reporter pointed out:

The locals, including the contractors, plot a direct correlation between the unhygienic circumstances in which they live and their 'criminal tendencies'. 'They don't care about anything else but money. They want to come to Kerala, live in the dirtiest of ways, commit a burglary and then leave', says Joseph Babu, a contractor.

(Thomas, 2013)

The contention that the problem lies with migrant workers diverts attention from state practices, policies, and social relations. Pointing out that it is the government and not migrant workers who are responsible for addressing problems of cleanliness and illegal activity, an activist described that it is the living conditions of migrant workers that foster ill health:

There is scarcity of clean water. They [migrant workers] do not have adequate toilet facilities. Ten to 20 people live in small huts. They are anonymous and there are no records. There is no system to provide vaccinations or other forms of necessary medical care to them.

(TB Mini cited in Shaheena, 2016)

The rape and murder of a young law student in 2016, which was eventually traced to a migrant worker, was a defining moment in mobilising legitimacy for surveillance of migrant workers. Multiple forms of marginality intersected in representations of the victim and the suspect. In the immediate aftermath of the crime, the media treated the victim, a Dalit from a poor family, with insensitively revealing her name and questioning her academic credentials before catapulting her into the position of 'Kerala's daughter' even as it generated paranoia about migrant labour (Zacharias, 2016).

Amidst growing tensions, a mob lynched a migrant worker who arrived in the state soon after the incident, reportedly on the suspicion that he was a thief. Bobby Thomas, a migrant rights activist pointed out: 
This is only a symptom of the abhorrence and intolerance that Malayalee society displays towards migrant workers. Now public demands for registering them with the police are on the rise ... Why police? The government has other mechanisms to keep a record of migrants coming to Kerala. Even local self-governments can play a role.

(Cited in Shaheena 2016)

The question exposes the failures of a benevolent state in protecting the rights of migrant workers in Kerala. Notably, fear of the police can prevent migrants from speaking openly. As 'the already existing xenophobia has increased', migrant workers were reluctant to speak of police interrogation or even their living or working conditions (Thomas cited in Shaheena, 2016).

But displacing the responsibility for crime on to migrant labour also diverts attention more specifically from the state's responsibility to ensure women's safety. A migrant activist is forced to state the obvious - that the problem of gender-based crime is not confined to migrant labour:

Instead of keeping the migrants under the scanner each time a rape is committed, Kerala's government and society must find ways to make the state a safer place for women to live in. The statistics being bandied about in the media amount to this: In 2015, every 43 minutes saw a new crime against a woman in the state. And, on average, a woman was raped almost every six hours. Few migrants, if any, have anything to do with this astounding crime rate.

(Fr PA Chacko, cited in Prasad, S. 2016)

An environment of suspicion that is generated in the wake of crime has served to remind migrant workers of their 'outsider' status. The rape and murder of a woman in Perambavoor in 2019 'brought back that by-now familiar sense of alienation that visits the likes of Rajendar [a migrant worker] every time a migrant is hauled up by police' (Praveen, 2019). Rajendar, who has spent the past two decades in Kerala, arriving in the state at the age of 16, told the reporter that people 'need to realise that every land has its share of good and bad people, and there is no place full of good people alone'. He lives in Perambavoor with his family in circumstances that could not be very different from those of Payal Kumari, whose academic achievement was celebrated. Both spoke fluently in Malayalam and their families worked hard to make a living in Kerala. Payal Kumari was quoted as saying that she felt so safe in Kerala that she could walk on the streets at night without causing concern to her parents and that she was never made to feel like an outsider (Kuriakose, 2020). While this may suggest a certain 
fluidity and layering in the experiences of migrants, the association of criminality with migrant workers exposes a bed rock of congealed hostility.

In contrast to individual achievements of migrants, whether in education, sports, or art, the marking of identity and difference are political acts that may be perceived as threats to sovereignty. What emerges from the above analysis is a binary view of migrant labour as a threat to public order who must therefore submit to state surveillance or quintessentially apolitical actors, whose achievements showcase the progressive credentials of the state. It is instructive, in this light, that the state sees welfare and surveillance as inextricably bound together. Epitomising this is the Awas scheme (see note 2), which was launched in the aftermath of the 2016 rape and murder case that exposed migrants to heightened suspicion. The objectives of the scheme were 'to ensure collection of information about inter-state migrant workers in Kerala and to provide health security'. Information referred to bio metrics and personal data of migrant workers (GO (Ordinary) no. 1365/2016, Department of Labour and Skills).

Crucially, the problem of migrant citizenship cannot be seen in isolation from the larger question of labour rights in Kerala. Routine forms of discrimination against migrant labour are evident in comparatively low wages (than that of local labour) and poor working and living conditions. Migrant labour is excluded from the significant gains made by local labour in both the formal and informal sectors. Mainstream trade unions are embedded in local structures of power and have colluded with big business interests to undermine the bargaining power of migrant workers (Prasad-Aleyamma, 2017). In this context, Prasad, M (2016) notes that migrant workers have sought to claim citizenship by forging alliances with their employers in the face of collusion by mainstream trade unions with the state and big businesses interests.

The All India Trade Union Congress, affiliated to the Communist Party of India, formed a separate Migrant Workers Union in 2013 but efforts to organise migrant workers are stymied by the conventional approach of organising designed for factory labour. The first state conference of the Kerala Migrant Workers' Union in 2017 acknowledged that rights achieved by local labour 'a long time ago' were not extended to migrant workers, who suffered from non-payment of minimum wages; exploitation by contractors; lack of proper living space; and proper service conditions, including health and shelter (The Hindu, 2 April 2017).

Interestingly, trade unions and the police fail to see that mobility is a condition that demands fundamental reworking of social and political institutions. The present structure of trade unions is too rigid to accommodate migrant labour except in separate unions that undermine labour solidarity. Being unconventional, the Self Employed Women's Association may offer 
a model as it registers membership in an umbrella organisation, irrespective of the place of work and occupation of the worker. Another way is to think in terms of portability of membership from place to place and even occupation to occupation given the nature of the times where necessary skill sets are subject to rapid change.

\section{Expatriate Malayali labour}

An estimated 3.0 million Keralites work in the Middle East. Of the approximately 3 lakh NRKs who had returned from COVID-19 hit countries by mid-April 2020, 1.65 lakh had lost their jobs (Kuttappan, 2020). The relations of the state with inter-state migrant workers, on the one hand, and NRKs, on the other, provide some instructive insights. The state appeals to NRKs in a language of merit that grants them a position of power and privilege. During the lockdown, for instance, the need to facilitate their return home was justified repeatedly with reference to their economic contributions or what the state owes to them as 'gratitude'. Also the two major political blocs in the state, the United Democratic Front and the Left Democratic Front, compete to be seen as the protectors of NRK interests. During the lockdown, the opposition accused the government of not being in earnest about facilitating the return of NRKs. A government order refusing to provide free quarantine for returning expatriates which said that Pravasis and 'guest workers' could not be treated as equal became hugely controversial, notwithstanding the substantially different costs that would be involved.

The efforts to woo NRKs are evidence of their collective power. Unlike in the case of inter-state migrant labour, state-conferred visibility of NRKs coincides substantially with visibility carved out by NRKs. Kerala is a pioneer in establishing a separate government department (Non Resident Keralites Association - NORKA) to serve the interests of NRKs. NORKA offers several welfare schemes for NRKs and returnee workers and has been organising the Loka Kerala Sabha, an occasion that like the Pravasi Divas celebrates expatriate achievements. During the lockdown, the government announced the Dream Kerala Project to tap the skills and experience of return migrants and also distributed Rs. 5,000 each to over 20,000 NRKs who were prevented from returning to the jobs. Going beyond welfare to a measure of political voice, representatives of NRKs are on the board of NORKA, whereas inter-state migrant workers are not involved in the design and governance of welfare schemes. NRKs also have their own associations to intervene in matters concerning them and to lobby with the government.

However, NRKs are not one homogeneous bloc. The celebration of the achievements of NRKs invariably excludes migrant domestic workers 
(MDW), comprising women mostly from economically distressed families who are possibly the single largest occupational group of women migrants from the state. There is little recognition of their substantial contribution to the betterment of some of the most socially marginal households in the state, those of widows and separated women (Kodoth, 2020). A discourse of merit that defines the government's response to male migrant workers and more affluent migrants has deleterious implications for groups that are not seen as worthy of celebration.

The visibility of MDWs in Kerala is defined usually by narratives of abuse and harassment, but these narratives have fallen strangely silent since the pandemic hit. Reports from the Middle East suggest that MDWs may be subject to increased workloads, paid lower salaries, at greater risk of contracting COVID because their jobs involve tasks of cleaning and close proximity with employers (Aoun, 2020). The Indian government outreach to domestic workers is usually poor and during the crisis there have been no specific measures to protect them. Many MDWs defy unjust state regulation, which restrict their right to mobility, and migrate to the Middle East through irregular channels. The government's approach to MDWs exposes the intersecting gender, class, and caste divide within Kerala and undermines citizenship (Kodoth, 2020).

\section{Conclusion: Search for justice-based solidarity}

Inter-state migrant labour in Kerala was granted a form of visibility through at least minimal social protection prior to and during the lockdown. At the same time, state practices and social relations have been implicated in producing them as 'outsiders' and denying them political rights. Thus, I have argued that state-conferred visibility has not guaranteed enfranchised citizenship. The analysis in the chapter presents two kinds of contrasts that underscore the failures of citizenship of inter-state migrant workers in Kerala and expose the faultlines of a benevolent state. While the extension of welfare to migrant workers and the celebration of their individual achievements are presented as seamless with a socially progressive and caring state and society, migrant protests are represented as a threat to sovereignty and the responsibility for crime committed by migrant workers is displaced en masse on to migrant labour. The second contrast is in the position of NRKs and inter-state migrant labour. Whereas the state appeals to NRKs in a language that grants them a position of privilege and power and state-conferred visibility coincides substantially with visibility sought by NRKs, the rhetoric of benevolence used to appeal to inter-state migrant workers and the discordance between state-conferred visibility and visibility staked by migrant workers underscore the failure of a benevolent state. 
However, NRKs are differentiated and among them MDWs are not seen as meritorious which indicates some similarities between the position of MDWs and that of inter-state migrant workers.

Mehta (2020) has pointed out that 'genuine solidarity, that speaks the language of justice, will ask hard questions about rights, institutional obligations, processes and accountability'. Labour rights are crucial to the issue of justice-based solidarity for migrant workers. At present, inter-state migrant labour is excluded from the substantial gains made by local labour in Kerala and has an uneasy relationship with the mainstream trade unions. Going further, as Samaddar (2020b: 39) observes the struggle for justice calls for the recognition of the vulnerabilities and struggles of people, which mandate a caring model of power that is socially regenerative, enriching of life, and produces solidarity. He argues that workplace rights and social protection are inadequate as migrant workers are invisible in politics (p 33). Indeed, in Kerala the spatial clustering of migrants could favour the emergence of migrant workers as elected representatives at the local level. The fear of and push back against migrant efforts to register their political existence and the binding of social protection to bureaucratic controls may be seen in this light.

\section{Notes}

1 Samaddar (2020a) points out that the exodus demonstrated the conditions in the informal economy and the near absence of social protection which fosters the circulation of workers between their villages and the cities, giving migrant workers little reason to remain in the destination and many reasons to leave.

2 The Kerala Migrant Workers Welfare Scheme, 2010, the first of its kind in the country, to provide accident/medical care for up to Rs. 25,000; Rs. 1 lakh to the family in case of death; children's education allowance; and termination benefits of Rs. 25,000 after five years of work to registered migrants. Awas offers registered workers free treatment of up to Rs. 25,000 from government empanelled hospitals and if a worker dies, the family receives Rs. 2 lakh as compensation. There is also the Roshini project aimed at inclusion of migrant children in schools and Changathi, a Malayalam literacy initiative for migrant workers.

3 The study estimated that there were about 2.5 million inter-state migrant workers in Kerala in 2013 and that the numbers could be expected to increase by about 2.35 lakh every year based on data on mobility from the railways (Narayana and Venkiteswaran, 2013).

4 SWAN (2020). For a discussion of gaps in implementation and responsiveness of higher-level state authorities, see also Roy (2020: 78).

5 Earlier in the year, a migrant woman from Bihar was similarly feted when she topped the Malayalam literacy exam with full marks (The Hindu, February 16, 2020). There are other examples as well such as an exhibition of paintings by a migrant worker from Bengal in Kozhikode (Shaheena, 2016). 


\section{References}

Ameerudhin, T.A., 2020. 'Vilification campaign mounts against migrant labourers in Kerala post lockdown protests', April 10. Retrieved from https://www.onm anorama.com/news/kerala/2020/04/10/villification-campaign-against-migrant -workers-in-kerala-after-lockdown-protests.html. Accessed on 15 October 2020.

Aoun, Rana, 2020. 'COVID-19 impact on female migrant domestic workers in the middle east', GBV AOR Helpdesk. Retrieved from https:/gbvaor.net/sites/ default/files/2020-05/COVID-19\%20and\%20Impact $\% 20$ on $\% 20$ Vulnerable $\% 2$ 0Female\%20Migrant\%20Domestic\%20Workers\%5B5\%5D.pdf. Accessed on 15 October 2020.

Arnimesh, Shanker, 2020. 'Rotis, mobile recharges, carrom boards - how Kerala fixed its migrant worker anger', Print, 18 April. Retrieved from https://theprin t.in/india/rotis-mobile-recharges-carrom-boards-how-kerala-fixed-its-migrant -worker-anger/403937/. Accessed on 15 October 2020.

Bhabha, J., 2011. 'Introduction', in J. Bhabha, ed., Children Without a State: A Human Rights Challenge, MIT Press: Cambridge, MA.

G.O. (Ordinary) no 1325/2016/labour, Government of Kerala, Department of Labour and Skills, dated 20/10/16.

G O no. 113/2020, Government of Kerala, Public distribution division, dated April 24.

G Plus News, 2020. 'SRC, India conducted webinar on 'COVID-19 and the handling of migrants: Kerala experiences’, G Plus News, 07 July.

Heller, Patrick, 2020. 'A virus, social democracy, and dividends for Kerala', The Hindu, 18 April.

Jena, Sujata, 2020. 'A good samaritan labour commissioner of Kerala and light at the end of a tunnel for Odisha guest workers', Countercurrents.org, 22 June.

Kodoth, Praveena, 2020. 'In the shadow of the state: Recruitment and migration of women as domestic workers to the middle east', Background Paper, International Labour Organisation, July.

Kuriakose, Ronnie, 2020. "My success belongs to Kerala": Migrant worker's daughter on securing first rank in MG varsity exam', Onmanorama, 26 August. Retrieved from https://www.onmanorama.com/news/kerala/2020/08/26/payal -kumari-migrant-workers-daughter-secures-first-rank.html. Accessed on 15 October 2020.

Kuttappan, Rejimon, 2020. '1.65 lakh Keralites returned from COVID-Hit countries due to job loss', 20 August. Retrieved from https://www.thelede.in/inclusion/20 20/08/20/165-lakh-keralites-returned-from-covid-hit-countries-due-to-job-loss. Accessed on 15 October 2020.

Mehta, Pratap Bhanu, 2020. 'Beyond solidarity: The migrant labour and the unemployed will be demanding their rights, not our mercy', Indian Express, 18 April. Retrieved from https://indianexpress.com/article/opinion/columns/coron avirus-covid-19-india-lockdown-migrant-labourers-6367384/. Accessed on 15 October 2020.

Narayana, D and C. S. Venkiteswaran, 2013. Domestic Migrant Labour in Kerala, GIFT, Thiruvananthapuram. 
Paliath, Shreehari, 2020. 'Now is the time to show India cares about its migrants', Interview with Binoy Peter, Indiaspend.com, 15 April. Retrieved from https:// www.indiaspend.com/now-is-the-time-to-show-india-cares-about-its-migrants/. Accessed on 15 October 2020.

Phillip, Shaju, 2020. 'In Kerala, migrant's daughter tops BA exam, earns CM's praise', Indian Express, 24 August.

Prasad, M., 2016. 'Migration and production of space: Labour, capital and the state in Kerala, India', Unpublished $\mathrm{PhD}$ thesis, Jawaharlal Nehru University, New Delhi.

Prasad, Srinivasa, 2016. 'Jisha rape and murder: Kerala must stop looking at all migrant workers with suspicion', FirstPost, 07 May. Retrieved from https://www .firstpost.com/india/jisha-kerala-migrant-workers-gulf-nations-rape-crime-again st-women-2769080.html. Accessed on 15 October 2020.

Prasad-Aleyamma, Mythri, 2017. 'Cards and carriers: Migration, identification and surveillance in Kerala, South India', Contemporary South Asia, doi:10.1080/09 584935.2017.1407293.

Praveen, M. P., 2019. 'Migrants rue being stamped as criminals', The Hindu, Kochi, 29 November.

PTI, 2020. 'Bihari migrant woman emerges topper in Malayalam literacy exam', The Hindu, 16 February.

Roy, Rajat, 2020. 'The sudden visibility of Sangram Tudu', in R. Samaddar, ed. Borders of an Epidemic in Borders of an Epidemic: COVID 19 and Migrant Labour, Calcutta Research Group, Kolkata pp 76-82.

Saikiran, KP., 2020. '58\% of migrant workers go back, Kerala to feel pinch', Times of India, 12 June.

Samaddar, Ranabir, 2020a. Introduction: Borders of an Epidemic in Borders of an Epidemic: COVID 19 and Migrant Labour, Calcutta Research Group, Kolkata, pp. $1-23$.

Samaddar, Ranabir, 2020b. Burdens of an Epidemic: A Policy Perspective on COVID 19 and Migrant Labour, Calcutta Research Group, Kolkata.

Shaheena, K.K., 2016. 'Migrant workers in Kerala: The stigma', Open the Magazine, 14 July. Retrieved from https://openthemagazine.com/features/india/migrant -workers-in-kerala-the-stigma/. Accessed on 15 October 2020.

Sudhir, T.S. 2016. 'In wake of dalit law student's rape, Kerala debates demand for a database of migrants', Scroll.in, 21 June. Retrieved from https://scroll.in/article /810312/in-wake-of-dalit-law-students-rape-kerala-debates-demand-for-a-data base-of-migrants. Accessed on 15 October 2020.

SWAN, 2020. '32 days and counting: COVID lockdown, migrant workers and the inadequacy of welfare measures in India', Stranded Workers Action Network, 1 May

Thomas, Suresh P., 2013. 'Fear and loathing in Kerala', fountainink.in, 04 Feb. Retrieved from https://fountainink.in/reportage/fear-and-loathing-in-kerala. Accessed on 15 October 2020.

Writ petition (Civil), 468/2020 in Supreme Court of India in the case Shri Alakh Alok Srivastava Vs Union of India.

Zacharias, Prabha, 2016. 'Perumbavoor rape shows why it's time Kerala did a self check about progressiveness', Indian Express, 13 May. 